\title{
Livelihood on Mud Crab Catchment: A Case Study of Sundarban Coast, West Bengal, India
}

\author{
Nandi NC, Pramanik SK
}

Social Environmental and Biological Association (SEBA), Kolkata

\begin{abstract}
*Corresponding author: Nandi N C, Social Environmental and Biological Association (SEBA), 33C, Madhab Halder Road, Behala, Kolkata, India - 700 034; Tel: +91-9788170750345; E-mail: nepalchandra.nandi@gmail.com
\end{abstract}

Citation: : Nandi NC, Pramanik SK (2017) Livelihood on Mud Crab Catchment: A Case Study of Sundarban Coast, West Bengal, India: J Fish Aquac Dev (2017): JFAD-103

Received Date: 20 January, 2017; Accepted Date: 26 January, 2017; Published Date: 07 February, 2017.

1. Crab catching, in the Sundarban coast is an age-old avocation of local poor populace of this region. Though it remains in its traditional form even today but there is increasing demand of live crabs in the local as well as export market and hence there is increasing catchment, livelihood dependency, decreasing catch per unit effort and clandestine catchment of mud crabs (Scylla spp.) including adult and undersize crabs from prohibited areas of Sundarban Biosphere Reserve (SBR). The increase in catchment of mud crabs is also due recent surge of mud crab fattening in coastal Sundarban areas $[1,2]$. The present case study is made out of a mud crab catching group who resort to hook fishing in prohibited Lothian Island which is one of the three Wildlife Sanctuaries of this Biosphere Reserve (SBR) in West Bengal. It indicates their preference for this profession over others like agricultural labour, daily wage, etc.

2. DuluNaiya (38), the Group Leader of 10 hook fishers from Dwariknagar, under Namkhana Police Station, who used to initiate their journey in the early morning at 5 am by using his country boat called Paukhato Lothian Island and return to the landing ghat after 5-8 hours, depending on the lunar period. Participant fisher catches 40-60 crabs per day and earns Rs.450/- to Rs. 800/- depending on the season, market price and market demand of the traders and exporters (Table 1).

\begin{tabular}{|c|c|c|c|c|}
\hline Fishing season & Tidal flux (Lunar periods) & Catch/ day (kg); No. of crabs/ hr & Earnings/day (Last year 2016) & Market price (January 2017) \\
\hline \multirow[t]{2}{*}{ Premonsoon } & High tide (11th to 5 th) & 4-7 kg / day 5-10 crabs/ hr & Rs. $450-500 /-$ & \multirow{6}{*}{$\begin{array}{l}\text { Less than } 100 \text { gm: Rs.80-100; } \\
\text { About } 100 \mathrm{gm}: \text { Rs } 100-200 /- \text {; } \\
\text { Size } 150-200 \mathrm{gm} \text { (female- } 300- \\
600 /- \text {; male } 200-400 /-; \text { 200gm } \\
\text { or more: female } 600-800 /- \text {, } \\
\text { berried female } 800-1000 /- \text {; } \\
\text { male } 500-600 /-\end{array}$} \\
\hline & Neap tide (6th to 10 th) & $5-7 \mathrm{~kg} /$ day $5-10 \mathrm{crabs} / \mathrm{hr}$ & Rs. 500-600/- & \\
\hline \multirow[t]{2}{*}{ Monsoon } & High tide (11th to 5 th) & 6-8 kg/ day $5-12 \mathrm{crabs} / \mathrm{hr}$ & Rs. $600-700 /-$ & \\
\hline & Neap tide (6th to 10th) & $8-10 \mathrm{~kg} /$ day $5-12 \mathrm{crabs} / \mathrm{hr}$ & Rs. $700-800 /-$ & \\
\hline \multirow[t]{2}{*}{ Post Monsoon } & High tide (11th to 5 th) & $3-5 \mathrm{~kg} /$ day $5-10 \mathrm{crabs} / \mathrm{hr}$ & Rs. 500-700/- & \\
\hline & Neap tide (6th to 10 th) & $5-7 \mathrm{~kg} /$ day $5-10 \mathrm{crabs} / \mathrm{hr}$ & Rs. $600-800 /-$ & \\
\hline
\end{tabular}

Note: During 2016 Dulu Naiya earned on an average Rs. 500/(Premonsoon), Rs. 700/- (Monsoon) and Rs. 650/- (post monsoon) but he earns Rs.100/- more everyday which he received as rent @ Rs. 10/- per head per day from participant hook fishers for using his boat in daily trip to Lothian Island and back (as informed to one of us - SKP) Earlier hook fishers of Fatikpur of Sundarbanestuaries was known to earn Rs. 364/- a month in 1993, collecting an estimated 640 crabs in 8 trips (weekly 2 trips of 2-3 days duration) with a total sale proceeds of Rs. 576/- after selling them at an average Rs. 18/- per score i.e., 20 crabs, spending an average expenditure of Rs. 212/- a month which include boat owner's charge (Rs. 25/-), fooding expenses of Rs. 150/-, permit charge Rs. $12 /-$ and pocket/ petty expenses of Rs. 25/- only [3]. These suggest that market price has increased manifold and as a result there is increasing exploitation as well as increasing conservation concern of mud crabs.

\section{References}

1. Pramanik SK NC Nandi (2012) Crab fattening (Chamber Chas) - a promising enterprise in Indian part of Sundarban. J. Environ. \& Sociobiol 9: 78.

2. Nandi NC, Pramanik SK (2015) Wetland economics. 2. Crab production in brackish water ponds of Sundarban, West Bengal. Nat. Sem. on Aqua resources: Care $\&$ Concerns, SEBA, Kolkata p: 9.

3. Nandi NC, Pramanik SK (1994) Crabs and Crab Fisheries of Sundarban. Hindusthan Publishing Corporation (India), Delhi 1- 192. 